\title{
PUBLIC ADMINISTRATION
}

DOI https://doi.org/10.51647/kelm.2020.4.3.1

\section{WEKTORY ZARZĄDZANIA PODTRZYMANIEM DZIAŁALNOŚCI PRZEDSIĘBIORSTW PRZEMYSLU SPOŻYWCZEGO}

\author{
Svitlana Markova \\ docent Katedry Administracji Biznesowej i Zarządzania Zagraniczna Działalnościa Gospodarcza, \\ Zaporoskiego Uniwersytetu Narodowego (Zaporoże, Ukraina) \\ ORCID ID: 0000-0003-0675-0235 \\ masvvi@outlook.com
}

\begin{abstract}
Adnotacja. Celem badania jest zdefiniowanie wektorów zarządzania podtrzymaniem działalności przedsiębiorstwa, jako podstawy istnienia i prowadzenia działalności gospodarczej w warunkach zagrożeń i słabości, wewnętrznego i zewnętrznego środowiska organizacji. W badaniu podano definicję kategorii ekonomicznej ,podtrzymywanie działalności przedsiębiorstwa”, a także opracowano koncepcyjny model tworzenia i zapewniania systemu zarządzania podtrzymywaniem działalności przedsiębiorstwa. Podkreślono znaczenie istnienia wpływu i kontroli czynników środowiska zewnętrznego i wewnętrznego na działalność firmy. Autor określa rolę czynników produkcji w tworzeniu podstaw podtrzymywania działalności przedsiębiorstwa. W badaniu przeprowadzono szczegółową analize SNW działalności przedsiębiorstwa przemysłu spożywczego. Analiza określiła istnienie wektorów, które pogarszają lub poprawiają pozycję firmy (wektory wzmocnienia lub osłabienia podtrzymywania działalności) i daje kierownictwu możliwość opracowania strategii uwzględniającej wektory osłabienia podtrzymywania działalności. W pracy przedstawiono mapę celów, których przestrzeganie i realizacja pozwoli przedsiębiorstwu poprawić poziom jego podtrzymywania działalności.

Słowa kluczowe: podtrzymywanie działalności, strategia, wektor, czynniki środowiska wewnętrznego i zewnętrznego, przemysł spożywczy.

\section{VECTORS OF LIFE SUPPORT MANAGEMENT OF FOOD INDUSTRY ENTERPRISES}

\author{
Svitlana Markova \\ Candidate of Sciences (Economics), Associate Professor, Department of Business Administration and \\ Management of Foreign Economic Activity \\ Zaporizhzhia National University (Zaporizhzhia, Ukraine) \\ ORCID ID: 0000-0003-0675-0235 \\ masvvi@outlook.com
}

\begin{abstract}
The purpose of the research is to define the vectors of life support management of the enterprise as the basis for the existence and conduct of business in the conditions of threats and weaknesses, internal and external environment of the organization. The study provided the definition of the economic category of «life support of the enterprise», as well as developed a conceptual model for the formation and provision of the life support management system of the enterprise. The influence of external and internal environmental factors on the company's activities was emphasized. The author determines the role of production factors in the creation of the foundations for the life support of the enterprise. The study conducted a detailed SNW analysis of the activities of the food industry. The analysis identified the existence of vectors that aggravate or improve the situation of the company (vectors of strengthening or weakening of life support) and enables top management to develop a strategy taking into account the vectors of life support weakening. The work provides a map of the goals, compliance and implementation of which will allow the company the level of its life support.
\end{abstract}

Key words: life support, strategy, vector, factors of internal and external environment, food industry.

\section{ВЕКТОРИ УПРАВЛІННЯ ЖИТТЕЗАБЕЗПЕЧЕННЯ ПІДПРИЕМСТВ ХАРЧОВОЇ ПРОМИСЛОВОСТІ}

\section{Світлана Маркова}

доцент кафедри бізнес-адміністрування і менеджменту зовнішньоекономічної діяльності, Запорізький національний університет (Запоріжжя, Україна)

ORCID ID: 0000-0003-0675-0235

masvvi@outlook.com

Анотація. Метою дослідження є визначення векторів управління життєзабезпечення підприємства, як основу існування і ведення бізнесу в умовах загроз і слабких сторін, внутрішнього і зовнішнього середови- 
ща організації. У дослідженні надано визначення економічної категорії «життєзабезпечення підприємства», а також розроблено концептуальну модель формування та забезпечення системи управління життєзабезпечення підприємства. Наголошено на важливості існування впливу та контролю факторів зовнішнього та внутрішнього середовища на діяльність компанії. Автор визначає, роль факторів виробництва у створенні засад для життєзабезпечення підприємства. У дослідженні проведений розгорнутий SNW-аналіз діяльності підприємства харчової промисловості. Аналіз визначив існування векторів, які погіршують або покращують становище компанії (вектори посилення або послаблення життєзабезпечення) та дає можливість топ-менеджменту розробити стратегію з урахуванням векторів послаблення життєзабезпечення. У роботі наведена карта цілей, дотримання та реалізація яких надасть змогу підприємству покращити рівень його життєзабезпечення.

Ключові слова: життєзабезпечення, стратегія, вектор, фактори внутрішнього та зовнішнього середовища, харчова промисловість.

Вступ. Сучасні умови діяльності підприємств визначаються жорсткою конкуренцією, динамічністю ринкової кон'юнктури, попитом споживачів, сучасними інноваційними тенденціями ведення бізнесу, постійно мінливим характером зовнішнього і нестабільністю внутрішнього середовища. В таких умовах планувати розвиток дуже складно, тому все більша частина компаній вимушена вибирати стратегію помірного зростання або стратегію скорочення, тобто адаптувати умови функціонування підприємства до таких, що є достатніми до досягнення життєзабезпечення підприємства. Для цього бізнес-одиниці потрібно ефективно використовувати наявні ресурси для досягнення максимального прибутку в умовах обмеженості природних, матеріальних, фінансових і трудових ресурсів. Таким чином, бізнес-середовище диктує «правила життя» (виживання), коли компанія має чітко спланувати кількість (якість) наявних ресурсів для життєзабезпечення, без якого підприємство швидко досягне стадії «спаду» і піде з ринку. Таким чином, в умовах турбулентності, як ніколи, виникає актуальне питання визначення стратегії управління життєзабезпечення підприємства.

Основна частина. Метою дослідження є визначення векторів управління життєзабезпечення підприємства, як основу його існування і ведення бізнесу в умовах загроз і слабких сторін діяльності та факторів внутрішнього і зовнішнього середовища організації.

Матеріал і методи досліджень. До фундаментальних праць зі стратегічного управління можна віднести роботи наступних зарубіжних авторів: Р. Акоффа, М. Альберта, І. Ансоффа, Р. Брейлі, Р.С. Каплана, Т. Коллера, М. Мескон (Мескон, 2009), М. Портера, Дж. Стрікленд, А. Томсона. Серед вітчизняних вчених, що аналізують проблеми теорії та практику стратегічного управління можна відзначити роботи таких авторів: А. Гершуні, А.Т. Зуба, Р.А. Фатхутдінова, Ю.В. Яковлєва та інших. На сьогоднішній день не існує досліджень, що розкривають зміст і сенс визначення стратегічного управління життєзабезпечення підприємства, тому вважаємо, дане питання є актуальним в умовах розвитку бізнес-середовища.

Для вирішення поставлених завдань було використано наступні методи: аналіз, синтез, узагальнення, аналогія, моделювання та системний підхід.

Результати та їх обговорення. Життєзабезпечення підприємства - це комплекс взаємопов'язаних заходів, що здійснюються спеціальними службами та підрозділами підприємства, спрямований на реалізацію місії та цілей, які перешкоджають економічним втрат і забезпечують продовження діяльності у майбутньому, а також передбачає активну взаємодію з факторами зовнішнього і внутрішнього середовища. Управління життєзабезпечення підприємства - важлива економічна категорія, яка демонструє здатність об'єкта управління справлятися з загрозами і слабкими сторонами діяльності. Володіючи певною кількістю чинників виробництва підприємство може протидіяти новим викликам від: конкурентів, стейкхолдерів (англ. Stakeholder в перекладі зацікавлена особа, група осіб), партнерів, споживачів та органів влади. Зауважимо, що термін життєзабезпечення був запропонований американським етнографом Р. Лоуі та означає власну технологію добування і виробництва їжі (для людини). Переклад англійської слова subsistence (дослівно «існування, прожиток, засіб підтримки життя») (Волгушева А.А. Жизнеобеспечение). Якщо характеристики даної категорії перенести на функціонування підприємства, отримаємо наступне: «життєзабезпечення підприємства - формування комплексу дій, норм і правил, спрямованих на забезпечення стійкого функціонування підприємства, тобто швидка здатність підприємства протидіяти негативному впливу факторів зовнішнього і внутрішнього середовища». Зауважимо, що підприємство повинно швидко вміти зреагувати на зміни в середовищі. У разі, якщо часу буде витрачено більше компанія ввійде до фази «спаду» життєвого циклу та подальшої її лікціваціїі. Будь-яка діяльність підприємства здійснюється відповідно до законів, норм, принципів розвитку, має відповідні об’єкти і суб'єкти впливу (рис. 1). На рисунку 1 представлена концептуальна модель формування та забезпечення системи управління життєзабезпечення підприємства (СУЖП). Забезпечення життєзабезпечення підприємства нерозривно пов'язане з факторами зовнішнього і внутрішнього середовища. 3 точки зору Масовий Н. (Моисеева, 2010) зовнішнє середовище організаціїсукупність активно діючих суб'єктів і сил, які знаходяться поза сферою безпосереднього контролю з боку керівництва підприємства і можуть вплинути в подальшому на їі стратегію. Саргсян С. М. (Саргсян, 2013: 105) визначає, що зовнішнє середовище включає, що в себе сили і організації, з якими фірма зіштовхується у своїй повсякденній і стратегічній діяльності. 


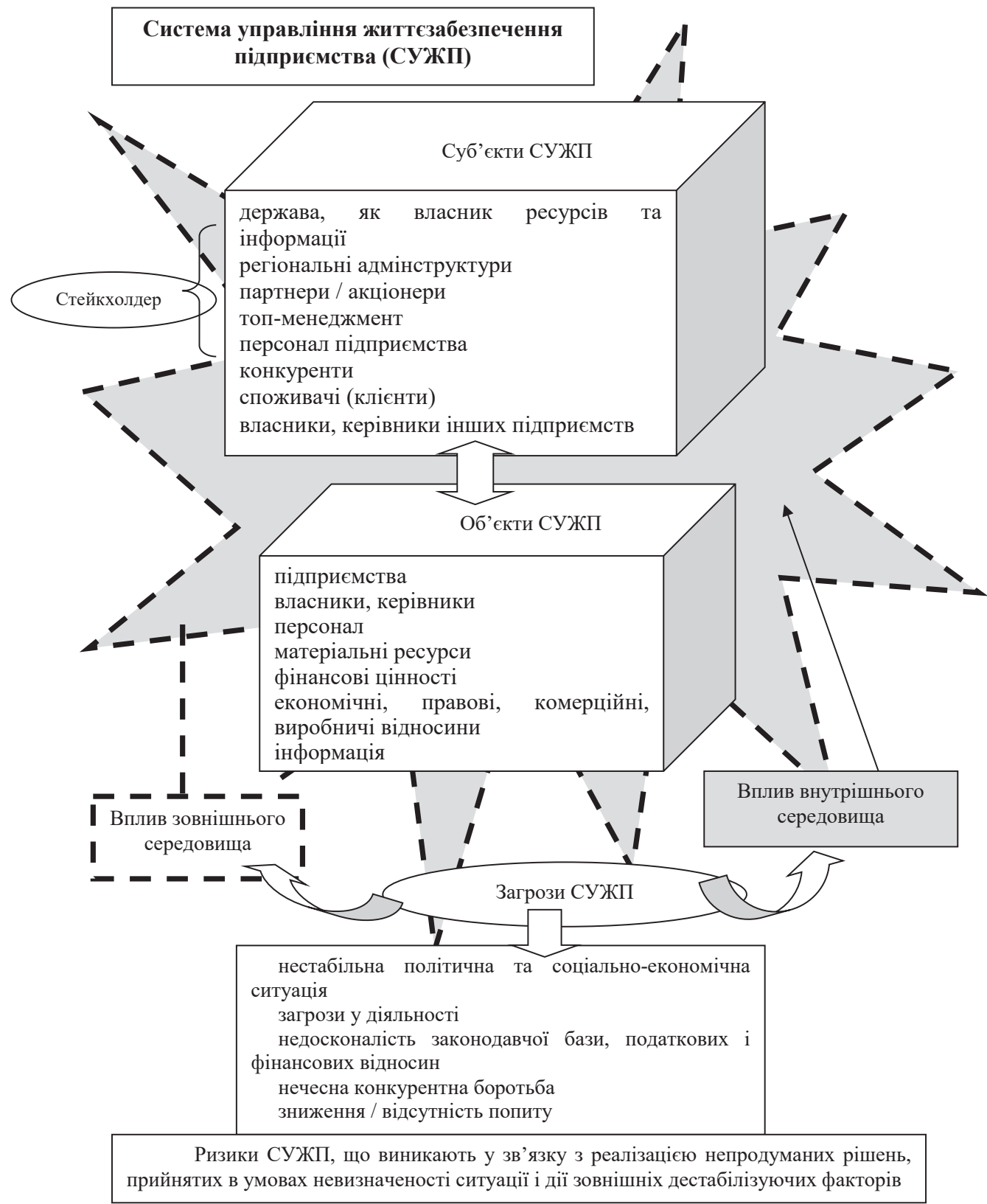

Рис. 1 Концептуальна модель формування та забезпечення СУЖП

На думку (Тюрина, 2012), внутрішне середовище організації - сукупність факторів, які визначають здатність і ступінь інтеграції організації в зовнішнє середовище. Внутрішнє середовище можна розглядати як в статичному стані, виділяючи склад елементів і культуру, так і в динаміці, вивчаючи процеси, що протікають під дією ряду факторів. Особливе місце у внутрішньому середовищі займають люди. Їх здібності, рівень освіти і кваліфікації, досвід роботи, спосіб мислення, мотивація і відданість визначають кінцевий результат роботи організації (Тюрина, 2012). Ми не можемо не погодитися, що персонал це найбільш важливий і незамінний фактор, без якого організація не зможе існувати. Також плинність кадрів веде до зниження продуктивність і результативність праці, оскільки новий співробітник не зможе показати такий же результат у роботі, як існуючий і вмотивований. Йдеться про втрати (часові і грошові) на адаптацію нового працівника.

Життєзабезпечення підприємства тісно пов'язана з джерелами зростання обсягів виробництва продукції. Основні причини виробничо-економічної діяльності та умови, в яких відбувається створення продукту або послуги, називають факторами виробництва. Вони є в певному сенсі рушійними силами виробництва, складовою частиною (формування) життєзабезпечення підприємства. Класики економіки зазвичай виділяють чотири основі фактори виробництва, під якими розуміються ресурси, які використовуються при створенні товарів або послуг. До факторів виробництва відносять:

- працю (труд);

- земля (земельні ресурси); 
- капітал (основні фінансово-економічні показники, обсяг і якісний склад основного і оборотного капіталу; механізми: оподаткування, кредитно-фінансові, страхові; ціноутворення, технологія виробництва, рівень державної підтримки, стимулювання праці);

- підприємницьку діяльність (якісні характеристики керівника, харизма лідера, аналіз розвитку виробництв, оцінка ефективності прийнятих рішень та їх корегування).

Еволюційний розвиток класичної теорії факторів виробництва знаходить своє відображення в працях Ж.Б. Сея (теорія «трьох факторів» виробництва). Схема розподілу продукту, за концепцією Сея, така: праця, капітал і земля розглядаються основними виробничими факторами; кожен із трьох факторів виробництва створює свою частку цінності продукту, який розподіляється у формі доходів: наймані робітники одержують заробітну плату, капіталісти (власники капіталу) - процент, земельні власники - ренту, підприємці - підприємницький дохід - за «діяльність, талант, керівництво» виробництвом. Отже, дохід на капітал - прибуток Сей розділив між власниками капіталу і підприємцями (керівниками виробництва) на процент і підприємницький дохід. При цьому в центрі механізму розподілу доходів знаходиться підприємець (Кузь, 2007: 93).

Єрмишин П. дає наступне визначення: «Під факторами виробництва розуміють особливо дуже важливі елементи або об’єкти, які здійснюють вирішальний вплив на можливість і результативність господарської діяльності» (Срмишин, 2002: 136).

В економічній науці поряд 3 поняттям «фактори виробництва» використовують і таку категорія як «ресурси виробництва». Вони становлять сукупність природних, капітальних і людських сил, які потенційно можуть бути використані в процесі виробництва. На відміну від ресурсів, фактори виробництва - це вже реально використані в процесі виробництва ресурси. Ще, фактори виробництва називають «працюючі ресурси», тобто елементи, що вже «включені», беруть учать у процесі виробництва. Наприклад, праця характеризується інтенсивністю і продуктивністю (рис. 2). Інтенсивність праці може зростати з урахуванням тривалості робочого дня i, навпаки, при збільшенні тривалості робочого дня інтенсивність праці може падати. Зауважимо, що праця, як фактор виробництва, має особливість, праця це товар - який оплачується не повністю. Ціна праці (заробітна плата) виражається здатністю людини до праці, інколи кількістю часу, який людина витрачає на поставлене завдання (погодинна оплата праці). Отже, оскільки товаром є не праця, а робоча сила, то і оплачується у формі заробітної плати не весь продукт праці, а лише частина його, необхідна для відтворення вартості робочої сили. Інша частина продукту праці є безоплатною.

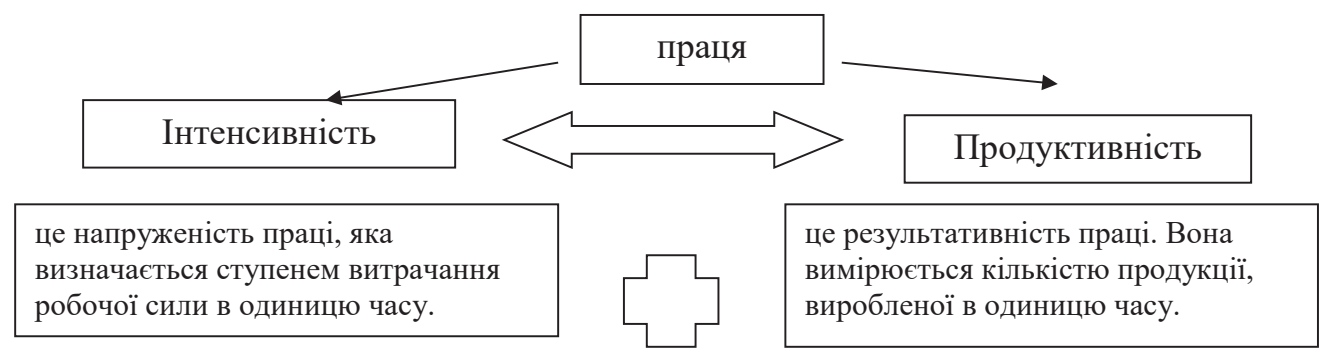

Рис. 2. Праця, як фактор виробництва

Наступним фактор виробництва, що характеризує життєзабезпечення підприємства - це земля. Вона, як фактор виробництва, об'єднує всі види природних ресурсів, всю сукупність природних явищ або об'єктів, які використовуються людьми для створення матеріальних та нематеріальних благ, забезпечення відтворення населення, підтримки умов існування людини, підвищення якості життя. До природних ресурсів належать безпосередньо земля, водні та лісові ресурси, корисні копалини, повітряний простір, флора і фауна та інші природні багатства, що використовуються у суспільному виробництві.

Особливостями (рис. 3) окремих природних факторів є неможливість їх переміщення (наприклад, орні землі) та штучного відтворення (наприклад, вугілля). Земля як фактор створення вартості є одним із найважливіших елементів виробництва. Для більшості українських підприємств не існує проблеми нестачі територій. Але щодо того, який вплив справляє земля на сукупну вартість, відповісти важко. Адже визнані і використовувані методики грошової оцінки земельних ділянок не дають змоги з'ясувати наскільки дана оцінка відповідає ринковій ціні (Давидов, 2014: 189).

Наступний фактор виробництва - це капітал (від лат. сарuta - голова) - це сукупність усіх створених людьми технічних і матеріальних засобів виробництва, а також грошові нагромадження, які використовуються у виробництві товарів та послуг. Для розрахунку використовують фінансово-економічні показники.

Підприємницькі здібності особливий, специфічний фактор виробництва, що характеризує діяльність людини стосовно поєднання та ефективного використання всіх інших факторів виробництва 3 метою створення благ та послуг. Підприємницькі здібності - особливий унікальний, рідкісний різновид людських ресурсів, один з видів складної творчої праці, який полягає у здатності найбільш ефективно поєднувати 
та використовувати інші фактори виробництва. Підприємницькі здібності передбачають здатність до генерування нових ідей, вміння визначити мету розвитку, організувати роботу колективу. Характерними рисами підприємців $є$ воля, честолюбство, наполегливість, вміння зосередитися на головному. Підприємництво сприяє постійному розвитку і вдосконаленню виробництва, підвищенню його ефективності та оновленню (Виробничі можливості суспільства).

\begin{tabular}{|c|c|c|}
\hline \multirow{7}{*}{ Земля } & має необмежений термін служби & + \\
\hline & є природним фактором, а не продуктом людської праці. & $+/-$ \\
\hline & $\begin{array}{l}\text { не піддається переміщенню, вільному переведенню з однієї } \\
\text { галузі виробництва в іншу, з одного підприємства на інше, } \\
\text { тобто вона нерухома }\end{array}$ & $+/-$ \\
\hline & $\begin{array}{l}\text { яка використовується в сільському господарстві, при } \\
\text { раціональній експлуатації не тільки не зношується, а й } \\
\text { покращує свою продуктивність }\end{array}$ & + \\
\hline & не зношується фізично та не старіє морально & + \\
\hline & $\begin{array}{l}\text { неможливо штучно відтворити (не відтворюється за } \\
\text { бажанням) }\end{array}$ & - \\
\hline & за розмірами має обмеженість*. & - \\
\hline
\end{tabular}

*Площа землі чітко обмежена поверхнею суші нашої планети і становить лише 29 \% від ії загальної площі. На Україні площа землі становить 61 млн га, в тому числі площа сільськогосподарських угідь - 42 млн га.

\section{Рис. 3 Особливості землі, як фактору виробництва}

Жоден з факторів сам по собі не спроможний створити та реалізувати продукт і принести прибуток власнику. Відсутність хоча б одного з них може привести до руйнування системи і зробити неможливим сам виробничий процес. Як економічна категорія життєзабезпечення підприємства грунтується на основних принципах (рис. 4).

Зауважимо, що основні принципи, які спрямовані на формування життєзабезпечення створюють взаємопов'язану систему, в той же час автор окремо виділяє принцип оптимальності, який зумовлює потребу такого варіанту, який відповідав би економічним критерієм ефективності господарської діяльності підприємства, максимум прибутку при мінімальних витратах. Даний принцип - як основа ведення бізнесу, тобто діяльність заснована на отриманні прибутку.

Кожна економічна категорія передбачає аналіз і отримання результату в наслідку впровадження. Так, результат життєзабезпечення - це постійний, неперервні процес функціонування компанії, який приносить результат не гірше (з урахуванням індексу інфляції) за попередній період (наприклад, рік). Автор вважає, що визначення і контроль рівня життєзабезпечення підприємства є важливим етапом стратегічного аналізу. Як відомо, стратегічний аналіз має широкий спектр інструментів: SWOT- аналіз, SNW-аналіз, SMART, TOWS-аналіз Вайхріха X. Останній метод, наприклад, базуються на виявленні факторів, що роблять істотний вплив як зсередини компанії, так і ззовні. Далі проводиться аналіз відповідності факторів внутрішнього середовища компанії вимогам зовнішнього середовища, в ході чого виявляються проблемні зони в діяльності організації. Незважаючи на те, що зазначені методики досить прості в застосуванні, особи, які проводять аналіз, можуть зіткнутися з деякими труднощами: визначення значущості кожного чинника, оцінка ступеня впливу цих факторів. Отже, результати такого аналізу можуть бути некоректними, спотворювати реальну ситуацію, що може істотно вплинути на вибір стратегічної альтернативи (Срмишин П. Г., 2002).

SNW аналіз - це інструмент стратегічного аналізу не тільки для відстежування поточного стану підприємства щодо конкурентів, а й часто використовується при стратегічному плануванні. Пов'язано це з тим, що SNW дозволяє виявити сильні сторони підприємства, в подальшому можна додатково підсилити ці сильні сторони, що в перспективі може створити ще більш сильну конкурентну перевагу. При цьому дана методика проведення аналізу передбачає і частковий пошук рішення. Це означає, що не просто виявляються слабкі сторони, але і робляться кроки по переводу цих сторін в нейтральні, тобто - по усуненню слабких сторін (План-Про plan-pro.ru). Ступінь ваги параметрів внутрішнього середовища діяльності оцінювалася експертами, фахівцями за 10-бальною шкалою.

TOВ «Урожай» (м. Запоріжжя) - українська компанія харчової промисловості з виробництва хліба та хлібних виробів. Персонал - висококваліфіковані спеціалісти (приблизно 300 осіб). Доля регіонального ринку становить близько $10 \%$. 


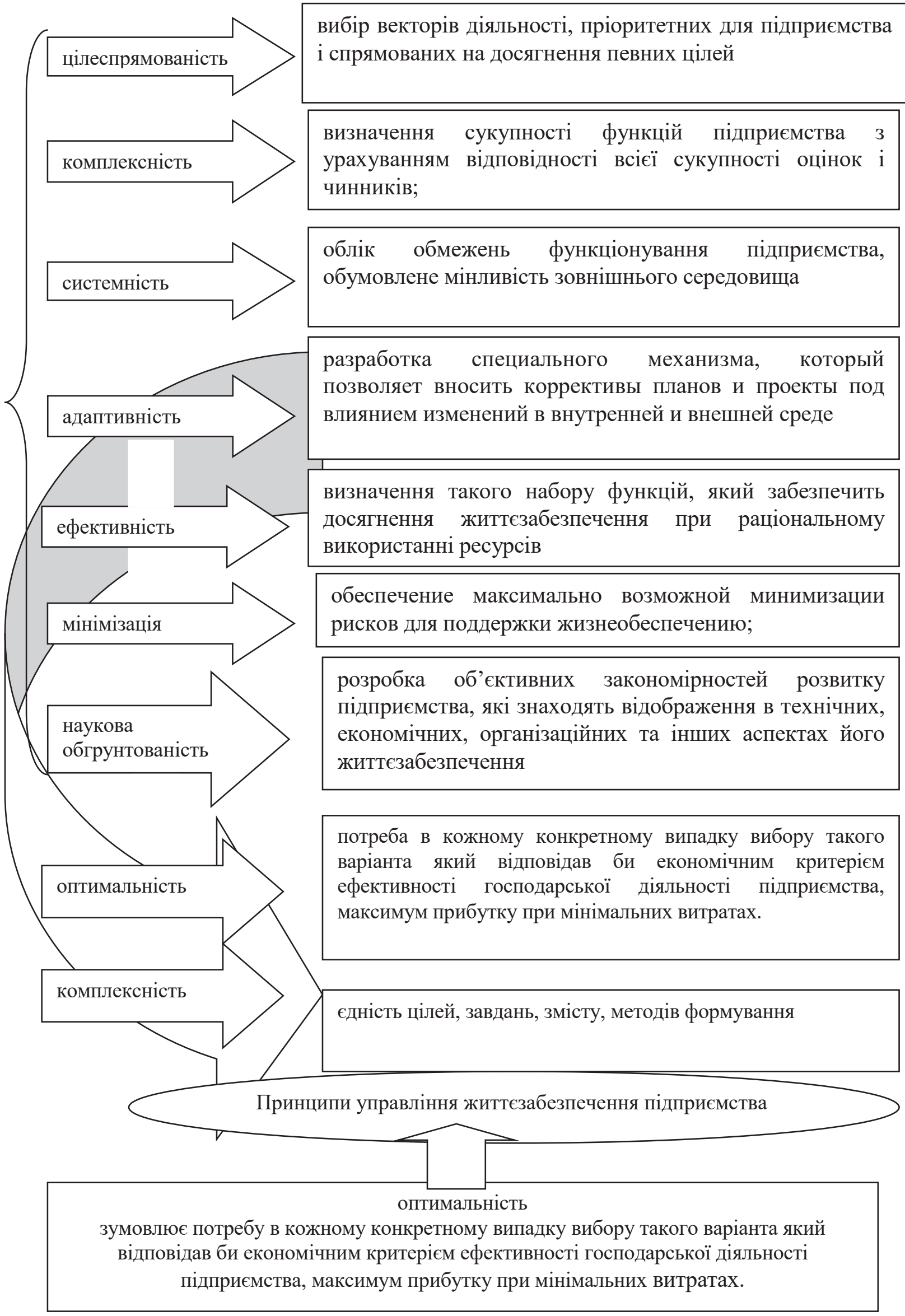

Рис. 4. Основні принципи управління життсзабезпечення підприсмства 
SNW-аналіз діяльності TOB «Урожай»

\begin{tabular}{|c|c|c|c|c|c|}
\hline & $\begin{array}{c}\text { номер } \\
\text { фактора }\end{array}$ & Ключеві параметри діяльності & $\begin{array}{c}\mathrm{S} \\
\text { сильна } \\
\text { сторона }\end{array}$ & $\begin{array}{c}\mathrm{N} \\
\text { нейтральна } \\
\text { сторона } \\
\end{array}$ & $\begin{array}{c}\text { W } \\
\text { слабка } \\
\text { сторона }\end{array}$ \\
\hline & 1 & 2 & 3 & 4 & 5 \\
\hline \multirow{6}{*}{ Праця } & 1 & Оновлення кваліфікації персоналу & 5 & & \\
\hline & 2 & Коефіцієнт стабільності персоналу & 9 & & \\
\hline & 3 & Відношення продуктивності праці і середньої заробітної плати & 7 & & \\
\hline & 4 & Плинність кадрів & & 5 & \\
\hline & 5 & Рівень інформаційного забезпечення & & & 4 \\
\hline & 6 & Організація комунікаційного процесу & & 5 & \\
\hline \multirow{5}{*}{ Капітал } & 7 & Відношення обсягу продажів до вартості активів & & 5 & \\
\hline & 8 & Фінансова стійкість & & 5 & \\
\hline & 9 & Рентабельність продукції & 8 & & \\
\hline & 10 & Частина ринка, яку контролює компанія & & & 3 \\
\hline & 11 & Асортимент продукції & & & 4 \\
\hline \multirow{5}{*}{ Земля } & 12 & Коефіцієнт зношеності основних фондів & & & 1 \\
\hline & 13 & Фондоємність & & 5 & \\
\hline & 14 & Географічна локація/ складність & & & 4 \\
\hline & 15 & Коефіцієнт оновлення основних фондів & & 6 & \\
\hline & 16 & Залежність від орендних площ & & & 8 \\
\hline \multirow{4}{*}{ 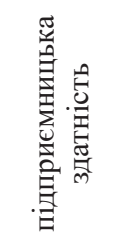 } & 17 & Соціальна активність підприємства / керівника & 8 & & \\
\hline & 18 & Репутація керівника & & 6 & \\
\hline & 19 & Якість продукції & 8 & & \\
\hline & 20 & Співвідношення витрат на маркетинг до загальних витрат & & 5 & \\
\hline
\end{tabular}

Таким чином, SNW аналіз - це важливий інструмент стратегічного аналізу внутрішнього і зовнішнього середовища, повнота і системність яка дасть можливість приймати управлінські рішення і для «забезпечення життя» підприємства (життєзабезпечення). Важливо зауважити, що SNW аналіз використовує думку експертної групи, яка повинна складатися з найбільш компетентних фахівців даної галузі, які здатні до аналізу і спрогнозувати закономірності для прийняття рішень щодо життєзабезпечення.

В табл. 1 наведений результат SNW-аналіза діяльності ТОВ «Урожай».

Аналіз таблиці 1 приводить до формування бази щодо векторів життєзабезпечення підприємства, а також топ-менеджменту потрібно негайно звернути увагу на слабки сторони підприємства (вектори послаблення життєзабезпечення), які найбільше загрожує життєзабезпеченню ТОВ «Урожай».

Таблиця 2

Вектори життсзабезпечення діяльності ТОВ «Урожай»

\begin{tabular}{|c|c|}
\hline $\begin{array}{c}\mathrm{S} \\
\text { вектори посилення життсзабезпечення }\end{array}$ & $\begin{array}{c}\text { W } \\
\text { вектори послаблення життєзабезпечення }\end{array}$ \\
\hline $\begin{array}{l}\text { Оновлення кваліфікації персоналу } \\
\text { Коефіцієнт стабільності персоналу } \\
\text { Відношення продуктивності праці і середньої заробітної плати } \\
\text { Рентабельність продукції } \\
\text { Соціальна активність підприємства / керівника } \\
\text { Якість продукції }\end{array}$ & $\begin{array}{l}\text { Рівень інформаційного забезпечення } \\
\text { Залежність від орендних площ } \\
\text { Географічна локація/ складність } \\
\text { Частина ринка, яку контролює компанія } \\
\text { Асортимент продукції } \\
\text { Коефіцієнт зношеності основних фондів }\end{array}$ \\
\hline
\end{tabular}

Зазначимо, що серед векторів, що послаблюють життєзабезпечення підприємства найбільш критичним є питання, щодо асортименту продукції. На 2021 рік асортимент ТОВ «Урожай» складає близько 130 позицій товару (у лідерів галузі ТМ «Хлібодар» у 2,5 рази більше). Топ-менеджмент компаній розуміє важливість вирішення даного питання, для цього була збудована «карта цілей» для покращення асортиментної політики.

Отже, досягнення поставлених цілей призведе до покращення асортиментної політики компанії харчової промисловості ТОВ «Урожай» у м. Запоріжжя. Це один з напрямів векторів розвитку, що дасть змогу покращити результати діяльності і зміцнити показники життєдіяльності підприємства. 


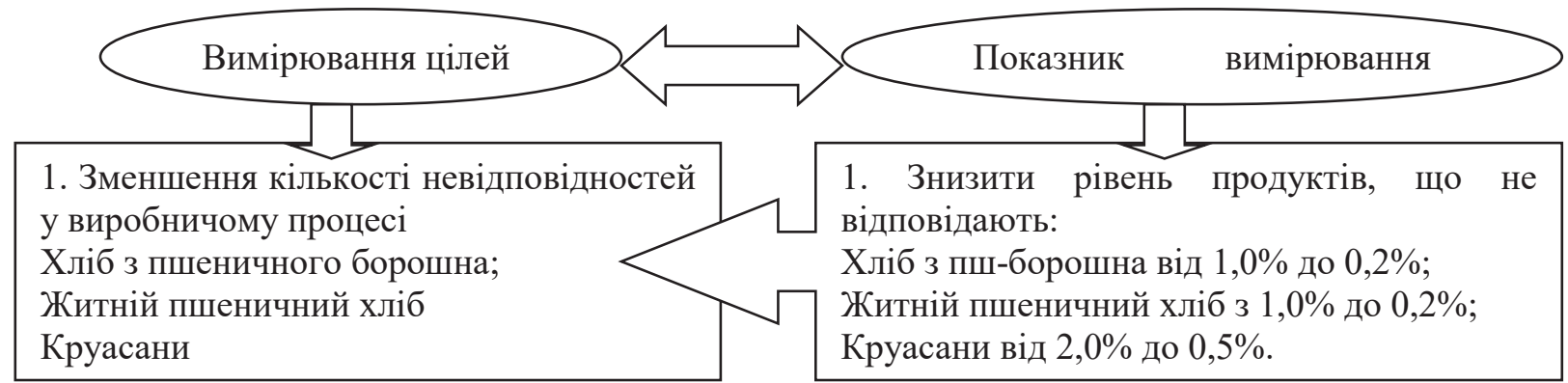

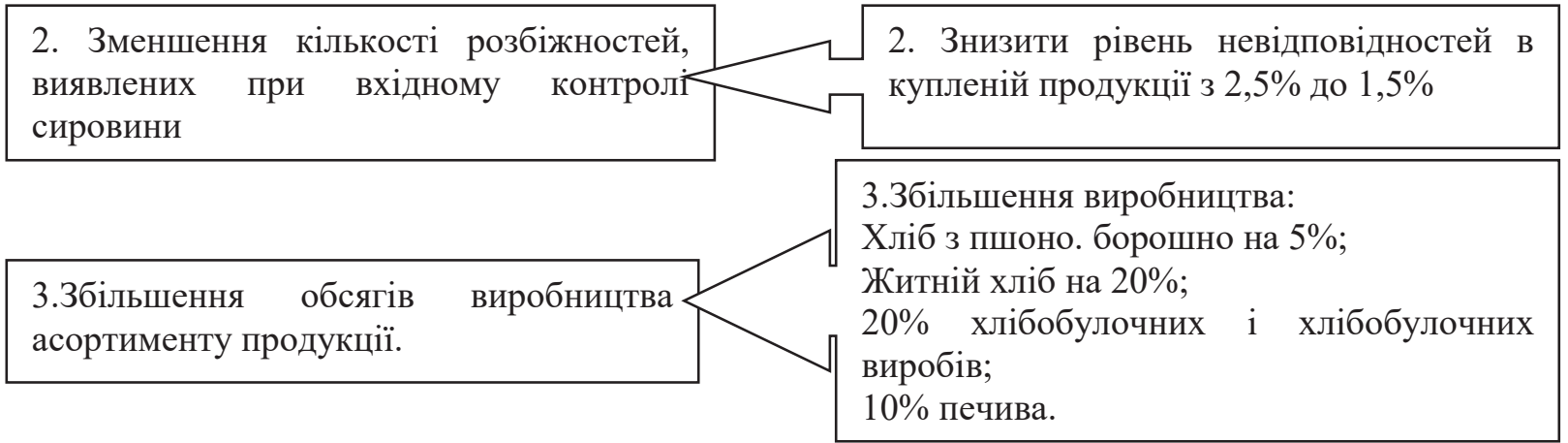
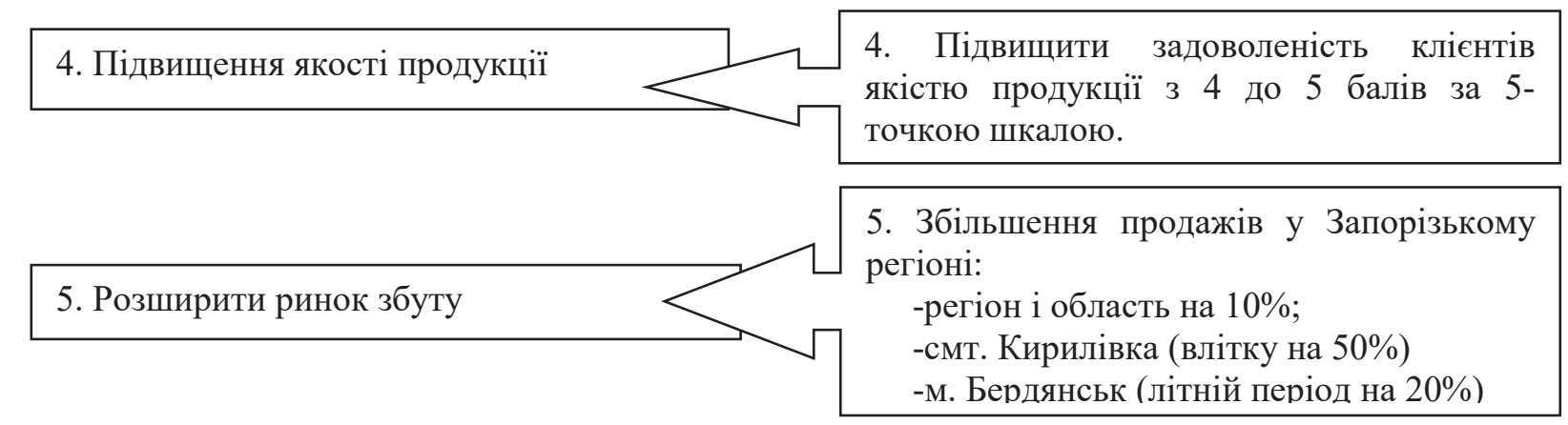

\begin{tabular}{ll}
\hline 6. Розширення технопарку & б. Придбання та монтаж додаткового \\
&
\end{tabular}

\section{Рис. 5. «Карта цілей» ТОВ «Урожай»}

Висновки. У даному дослідженні було проаналізовано основні економічні аспекти життєзабезпечення підприємств. Аналіз визначив існування векторів, які погіршують або покращують становище компанії, виокремлена категорія життєзабезпечення, як формування комплексу дій, норм і правил, спрямованих на забезпечення стійкого функціонування підприємства тобто швидка здатність підприємства протидіяти негативному впливу факторів зовнішнього і внутрішнього середовища. Розроблена концептуальна модель формування та забезпечення система управління життєзабезпечення підприємства (СУЖП). В роботі виявлено основні принципи, що активізують розвиток та створюють умови для стабільного життєзабезпечення підприємства.

Список використаних джерел:

1. Мескон М. Х. Основы менеджмента / Мескон М. Х., Альберт Х. М., Хедоури Ф.; пер. с англ. и ред. О. И. Медведь.3-е изд., передел. и доп. - К. : Издат. дом Вильямс, 2009. - 665 с.

2. Волгушева А.А. Жизнеобеспечение... - [Електронний ресурс]. - Режим доступу: https://center-yf.ru/data/stat/ zhizneobespechenie-cheloveka-eto.php

3. Моисеева Н.К. Стратегический менеджмент / Н.К. Моисеева. - М.: МИЭТ, 2010. - 220 с.

4. Саргсян С.Г. Анализ факторов внешней среды в компаниях пищевой промышленности / С.Г. Саргсян // Экономика, Статистика и Информатика. - 2013. - № 4. - С. 103-107.

5. Тюрина А. Учебное пособие по теории организации Электрон. текстовые данные [Електронний ресурс] / A. Тюрина - Саратов: Научная книга, 2012. - 159 c. URL: http://www.iprbookshop.ru/6349.html

6. Кузь В.І. Фактори виробництва та дохід від їх використання справедливе відображення в обліку / В.І. Кузь // ВІСНИК ЖДТУ. - 2007. - № 1 (39). - С. 93.

7. Єрмишин П. Г. Основи економічної теорії / П. Г. Єрмишин. - К.: Вища школа, 2002. -450 с.

8. Грішнова О.А. Економіка праці та соціально-трудові відносини: підручник / О.А. Грішнова - Київ: Знання, 2004. $356 \mathrm{c}$. 
9. Давидов О.І. Зростання вартості підприємництва як цільовий критерій управління / О.І. Давидов // Актуальні проблеми економіки. - 2014. - № 9. - С. 186-195

10. Виробничі можливості суспільства. Соціальна сутність виробництва. - [Електронний ресурс]. - Режим доступу: nlu.edu.ua

11. SNW аналіз. План-Про [Електронний ресурс]. - Режим доступу: plan-pro.ru

\title{
References:
}

1. Meskon, M.Kh. Albert, Kh.M. \& Khedoury, F. (2009) Osnovi menedzhmenta [Management basics]. (O. Y. Medved, Trans). (3d ed., rev.). Kyiv: Izdat. dom Vyliams. [in Russian].

2. Volhusheva, A.A. Zhyzneobespechenye... (n.d.). https://center-yf.ru/ Retrieved from https://center-yf.ru/data/stat/ zhizneobespechenie-cheloveka-eto.php

3. Moyseeva, N.K. (2010). Stratehycheskyi menedzhment. [Strategic management]. Moscow: MYET. [in Russian]

4. Sarhsian, S.H. (2013). Analiz faktorov vneshnej sredy v kompaniyah pishchevoj promyshlennosti [Analysis of environmental factors in food companies.]. Ekonomika, Statistika i Informatika-Economics, Statistics and Informatics, 4, 103-107. [in Russian].

5. Tiuryna, A. (2012). Uchebnoe posobie po teorii organizacii Elektron. tekstovye dannye [A tutorial on the theory of the organization Electron. text data.]. Saratov: Nauchnaia knyha. Retrieved from http://www.iprbookshop.ru/6349.html [in Russian].

6. Kuz, V.I. (2007). Faktory vyrobnytstva ta dokhid vid yikh vykorystannia spravedlyve vidobrazhennia v obliku. [Factors of production and income from their use are fairly reflected in accounting.] VISNYK ZhDTU-BULLETIN OF ZhSTU, 1 (39), 93 [in Ukranian].

7. Yermyshyn, P.H. (2002). Osnovy ekonomichnoi teorii. [Basics of economic theory]. Kyiv: Vyshcha shkola [in Ukrainian].

8. Hrishnova, O.A. (2004). Ekonomika pratsi ta sotsialno-trudovi vidnosyny: pidruchnyk. [Economics of labor and social and labor relations: textbook]. Kyiv: Znannia [in Ukrainian].

9. Davydov, O.I. (2014). Zrostannia vartosti pidpryiemnytstva yak tsilovyi kryterii upravlinnia. [Zrostannia vartosti pidpryiemnytstva yak tsilovyi kryterii upravlinnia.]. Aktualni problemy ekonomiky - Current economic problems, 9, 186-195 [in Ukrainian].

10. Vyrbnychi mozhlyvosti suspilstva. Sotsialna sutnist vyrobnytstva. ... (n.d.). nlu.edu.ua Retrieved from nlu.edu.ua [in Ukrainian].

11. SNW analiz. Plan-Pro plan-pro.ru Retrieved from plan-pro.ru [in Ukrainian].

DOI https://doi.org/10.51647/kelm.2020.4.3.2

\section{FINANSOWY SKŁADNIK POLITYKI PUBLICZNEJ W ZAKRESIE BEZPIECZEŃSTWA NARODOWEGO I OBRONY NA UKRAINIE}

\author{
Antonina Murashko \\ aspirat, \\ Narodowy Uniwersytet „Politechnika Czernihowska” (Czernihów, Ukraina) \\ ORCID ID: 0000-0002-6991-2003 \\ myrasko_a@ukr.net
}

\begin{abstract}
Adnotacja. Artykuł określa kluczowe cechy komponentu finansowego polityki publicznej w zakresie bezpieczeństwa narodowego i obrony Ukrainy na obecnym etapie. Przeanalizowano perspektywy wydatków na obronę na Ukrainie i za granicą. Zidentyfikowano sposoby bardziej racjonalnego wykorzystania dostępnych środków finansowych i skupiono się na zwiększeniu finansowania bezpieczeństwa narodowego i obrony w celu zapewnienia ich długoterminowego rozwoju i wzmocnienia zdolności obronnych naszego państwa.

Procesy ekonomicznego zapewnienia bezpieczeństwa narodowego na Ukrainie w ostatnich latach charakteryzują się różnorodnością i złożonością. Za ich główną treść można uznać zmiany w systemie zarządzania gospodarką wojskową w ogóle i tworzenie produktów wojskowych, w szczególności broni, a także znaczące zmiany w wojskowej polityce budżetowej i transformacji polityki wojskowej i społecznej Ukrainy.

Słowa kluczowe: wojskowy budżet obronny, polityka publiczna, bezpieczeństwo narodowe i obrona, składnik finansowy, budżet obronny kraju; państwowy system przygotowania do obrony.
\end{abstract}

